\title{
Two High Throughput Screen Assays for Measurement of TNF- $\alpha$ in THP-1 Cells
}

\author{
Kristin P. Leister, Ruili Huang, Bonnie L. Goodwin, Andrew Chen, Christopher P. Austin and \\ Menghang Xia*
}

\author{
NIH Chemical Genomics Center, National Human Genome Research Institute, National Institutes of Health, Bethesda, \\ MD 20892, USA
}

\begin{abstract}
Tumor Necrosis Factor- $\alpha$ (TNF- $\alpha)$, a secreted cytokine, plays an important role in inflammatory diseases and immune disorders, and is a potential target for drug development. The traditional assays for detecting TNF- $\alpha$, enzyme linked immunosorbent assay (ELISA) and radioimmunoassay, are not suitable for the large size compound screens. Both assays suffer from a complicated protocol, multiple plate wash steps and/or excessive radioactive waste. A simple and quick measurement of TNF- $\alpha$ production in a cell based assay is needed for high throughput screening to identify the lead compounds from the compound library. We have developed and optimized two homogeneous TNF- $\alpha$ assays using the HTRF (homogeneous time resolved fluorescence) and AlphaLISA assay formats. We have validated the HTRF based TNF- $\alpha$ assay in a 1536-well plate format by screening a library of 1280 pharmacologically active compounds. The active compounds identified from the screen were confirmed in the AlphaLISA TNF- $\alpha$ assay using a bead-based technology. These compounds were also confirmed in a traditional ELISA assay. From this study, several beta adrenergic agonists have been identified as TNF- $\alpha$ inhibitors. We also identified several novel inhibitors of TNF- $\alpha$, such as BTO-1, CCG2046, ellipticine, and PD 169316. The results demonstrated that both homogeneous TNF- $\alpha$ assays are robust and suitable for high throughput screening.
\end{abstract}

Keywords: AlphaLISA technology, HTRF technology, inhibition of TNF- $\alpha$ production, qHTS, TNF- $\alpha$, 1536-well plate.

\section{INTRODUCTION}

There are three members in the family of tumor necrosis factors (TNF): TNF- $\alpha$, TNF- $\beta$ (also called lymphotoxin $\alpha$, LT- $\alpha$ ) and LT- $\beta$ [1]. TNF- $\alpha$, a $17 \mathrm{kDa}$ cytokine, is mainly secreted by activated macrophages [2] and monocytes [3] in response to several inflammatory and immunological stimuli. For example, during bacterial infection, lipopolysaccharide (LPS), a component of gram-negative bacterial cell wall, induces the release of TNF- $\alpha$, one of numerous endogenous cytokines [4]. TNF- $\alpha$ plays an essential role in the immune system [4-6]; where it is involved in inflammation, tumor necrosis, inhibition of viral replication, and in some cases programmed cell death. At the cellular level, TNF- $\alpha$ regulates multiple signaling pathways, such as apoptosis and NF$\mathrm{kB}$ activation, through its cell surface receptors, TNF- $\alpha$ receptor type 1 (TNFR1) and TNF- $\alpha$ receptor type II (TNFR2) [7]. For example, TNF- $\alpha$ binding to TNFR1 initiates a series of cellular events, such as activation of a group of kinases which includes mitogen-activated protein kinase kinases (MEKKs), mitogen-activated protein kinases (MAPKs), and inhibitor of nuclear factor- $\mathrm{KB}$ kinase kinases (IKKs). Activation of these kinases leads to the regulation of down stream target gene expression, such as cytokines, chemokines and proteases [7].

Overproduction of inflammatory cytokines, such as TNF$\alpha$, has been linked to inflammatory disorders such as Crohn's

*Address correspondence to this author at the National Institutes of Health, National Human Genome Research Institute, NIH Chemical Genomics Center, 9800 Medical Center Drive, Bethesda, MD 20892-3370, USA; Tel: 301-217-5718; Fax: 301-217-5736; E-mail: mxia@mail.nih.gov disease (CD) and inflammatory bowel disease [8,9]. Currently, the most effective treatments approved by the FDA for CD are the protein-based TNF- $\alpha$ antagonists such as infliximab and adalimumab [9]. Natural products have also been investigated, due to several potential side effects of these protein-based TNF- $\alpha$ inhibitors. Several small molecule natural products including etanercept, reservatrol, curicumin, and lycorine have been found to reduce TNF- $\alpha$ levels, and may be an alternative approach to the development of small molecule inhibitors to suppress TNF- $\alpha$ signaling [7].

In order to screen large amounts of compounds to identify new inhibitors that block TNF- $\alpha$ secretion, a fast and simple assay format is needed. Currently, the most common available methods for TNF- $\alpha$ measurement are ELISA (Enzyme Linked ImmunoSorbent Assay) and radioisotope labeled immune assay. However, these assays have complicated assay protocols including several wash steps with long incubations and generation of a large amount of radioactive waste, which limits the screen throughput. In this study we have developed two homogenous TNF- $\alpha$ assays using HTRF-based and AlphaLISA-based assay formats. Both assays have been miniaturized into a 1536-well plate format and validated in a quantitative high throughput screening (qHTS) platform [10].

\section{MATERIALS AND METHODS}

\section{Cell Line and Culture Conditions}

The THP-1 (Human Acute Monocytic Leukemia) cell line was obtained from American Type Culture Collection (ATCC TIB-202; Manassas, VA). THP-1 cells, which origi- 
nate from the blood of a boy with acute monocytic leukemia [11], were cultured in RPMI 1640 (ATCC) medium supplemented with $10 \%$ fetal bovine serum (FBS, Thermo Scientific HyClone, Logan, UT, USA), $50 \mathrm{U} / \mathrm{ml}$ penicillin and 50 $\mu \mathrm{g} / \mathrm{ml}$ streptomycin (Invitrogen, CA), and $0.05 \mathrm{mM} \mathrm{2-}$ Mercaptoethanol (Invitrogen). The cell cultures were maintained in a $37^{\circ} \mathrm{C}$ incubator with $5 \% \mathrm{CO}_{2}$ and under a humidified atmosphere.

\section{Chemical Compounds}

A library of pharmacologically active compounds (LOPAC), containing 1280 compounds with known pharmacological actives, was purchased from Sigma (St. Louis, MO). Lipopolysaccharides (LPS), dobutamine hydrochloride, ellipticine, histamine dihydrochloride, Bay 11-7085, PD 169316, BTO-1, and IRAK-1/4 Inhibitor I were obtained from Sigma. CCG-2046 was purchased from Tocris Bioscience (Ellisville, MO).

\section{HTRF-Based TNF- $\alpha$ Assay and qHTS}

The secreted Human TNF- $\alpha$ in the cell culture medium of THP-1 cells was measured using an assay kit (Cisbio Bioassays, Bedford, MA, USA) based on the HTRF format (Fig. 1). HTRF $[12,13]$ combines standard FRET (fluorescence resonance energy transfer) technology with time-resolved fluorescent measurement, which could eliminate short-lived background fluorescence. For the assay optimization, THP-1 cells suspended in culture medium were dispensed at 2000, 3000 or 4000 cells $/ 5 \mu \mathrm{L} /$ well in 1536 -well white solid plates (Greiner Bio-One North America, Monroe, NC) using a Bioraptr dispensing system (Aurora Discovery, CA, USA). Twenty-three $\mathrm{nL}$ of LPS, a known TNF- $\alpha$ inducer [4], at final concentration ranging from $0.56 \mathrm{ng} / \mathrm{ml}$ to $9.2 \mu \mathrm{g} / \mathrm{ml}$ was transferred to the assay plate by a pintool work station (Kalypsys, San Diego, CA). The assay plates were incubated at $37^{\circ} \mathrm{C}$ for 5,17 , or $24 \mathrm{hr}$, followed by addition of $5 \mu \mathrm{L}$ mixture of cryptate labeled and XL665 labeled anti-TNF $\alpha$ antibodies. After the assay plates were incubated at room temperature (RT) for $3 \mathrm{hr}$, the plates were measured by a plate reader in a HTRF detection mode.

The TNF- $\alpha$ antagonist screening was described in Fig. 2. Briefly, THP-1 cells were dispensed at 3000 cells $/ 4 \mu \mathrm{L} /$ well in 1536-well white solid bottom plates, followed by an addition of $23 \mathrm{~nL}$ compound in DMSO soultion from LOPAC library or DMSO only with a pintool work station (Kalypsys). Each compound was screened at 7 final concentrations ranging from $2.9 \mathrm{nM}$ to $46 \mu \mathrm{M}$, as the DMSO solutions of compound library was titrated at $1: 5$ ratio. After a 5 to 10 min incubation, $1 \mu \mathrm{L}$ LPS in assay medium at $5 \mu \mathrm{g} / \mathrm{mL}$ LPS (final concentration of $1 \mu \mathrm{g} / \mathrm{mL}$ ) was dispensed into the assay plates by a Bioraptr dispensing system. The assay plates were incubated for 17 hours at $37^{\circ} \mathrm{C}$, followed by addition of $5 \mu \mathrm{L}$ mixtures of cryptate labeled anti-TNF $\alpha$ antibody and XL665-labeled TNF- $\alpha$ antibody. After the assay plates were incubated at RT for $3 \mathrm{hr}$, the dual fluorescence emissions of 615 and $665 \mathrm{~nm}$ with a $320 \mathrm{~nm}$ excitation were measured using an Envision plate reader (Perkin Elmer, Shelton, CT). The results were expressed as the ratio of $665 \mathrm{~nm} / 615 \mathrm{~nm}$ emissions. The signal (ratio) was reciprocally reduced with the increase of secreted TNF- $\alpha$ in the medium. There was no detergent in the assay buffer for this TNF- $\alpha$ assay. Thus, the cells in each well were kept intact and only the secreted TNF- $\alpha$ was detected.

\section{Hit Compounds}

After primary screening, the selected actives were cherry-picked and re-tested for the inhibition of LPS induced TNF- $\alpha$ production in 24 point titrations with final concentration ranging from $6 \mathrm{pM}$ to $46 \mu \mathrm{M}$ in a HTRF human TNF- $\alpha$

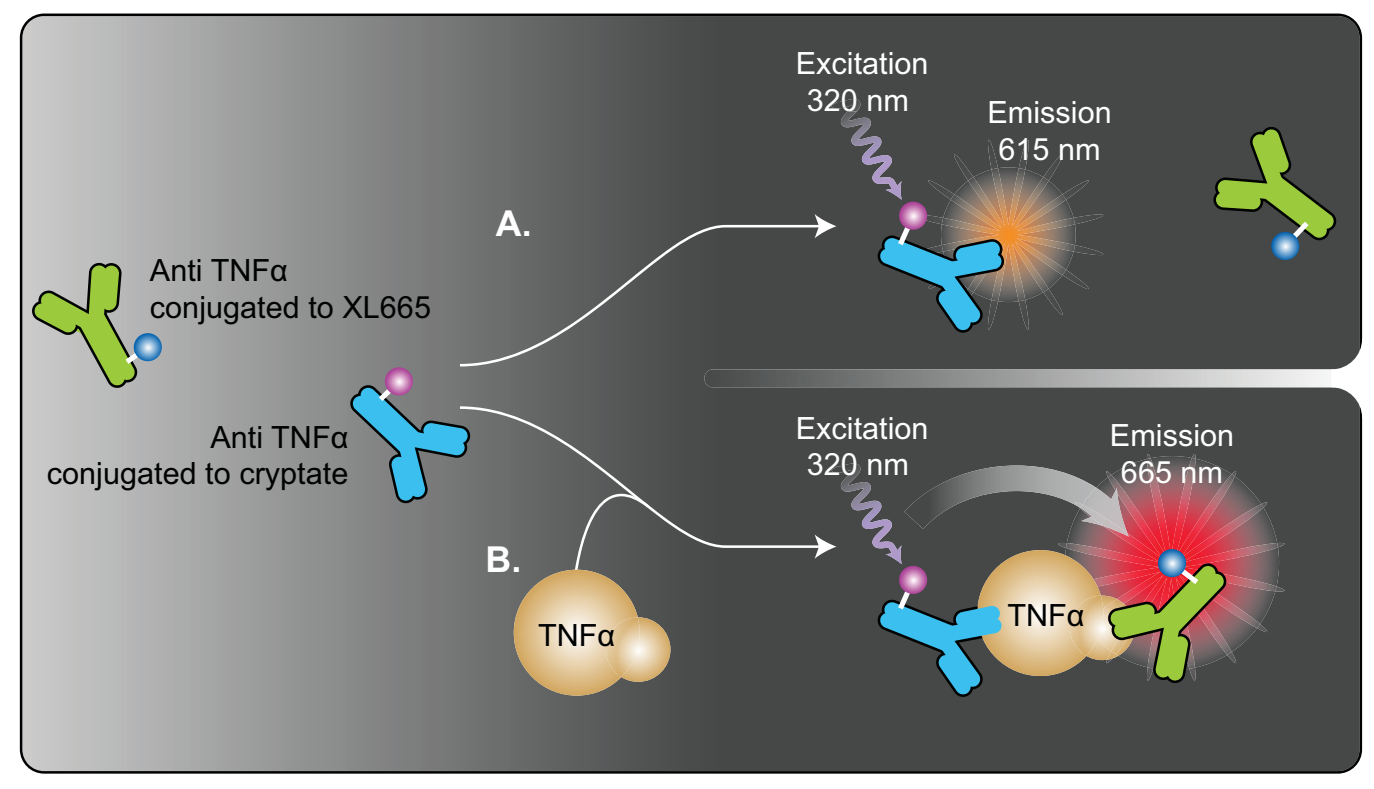

Fig. (1). Principle of HTRF-based TNF- $\alpha$ assay. The assay was designed using time resolved fluorescence resonance energy transfer (TRFRET) technology. In this assay, two anti-TNF- $\alpha$ antibodies are labeled with europium Cryptate and XL665, respectively. In the absence of TNF- $\alpha$, there is no FRET between these two labeled antibodies, which produces fluorescent signal at $615 \mathrm{~nm}$ (Fig. 1A). When TNF- $\alpha$ is present, these two labeled antibodies are brought into close proximity of each other, which allows FRET to occur between the two fluorophores, europium Cryptate and XL665 (Fig. 1B). This reaction produces a fluorescent signal at $665 \mathrm{~nm}$. The increase of FRET levels is proportional to the concentrations of TNF- $\alpha$. 


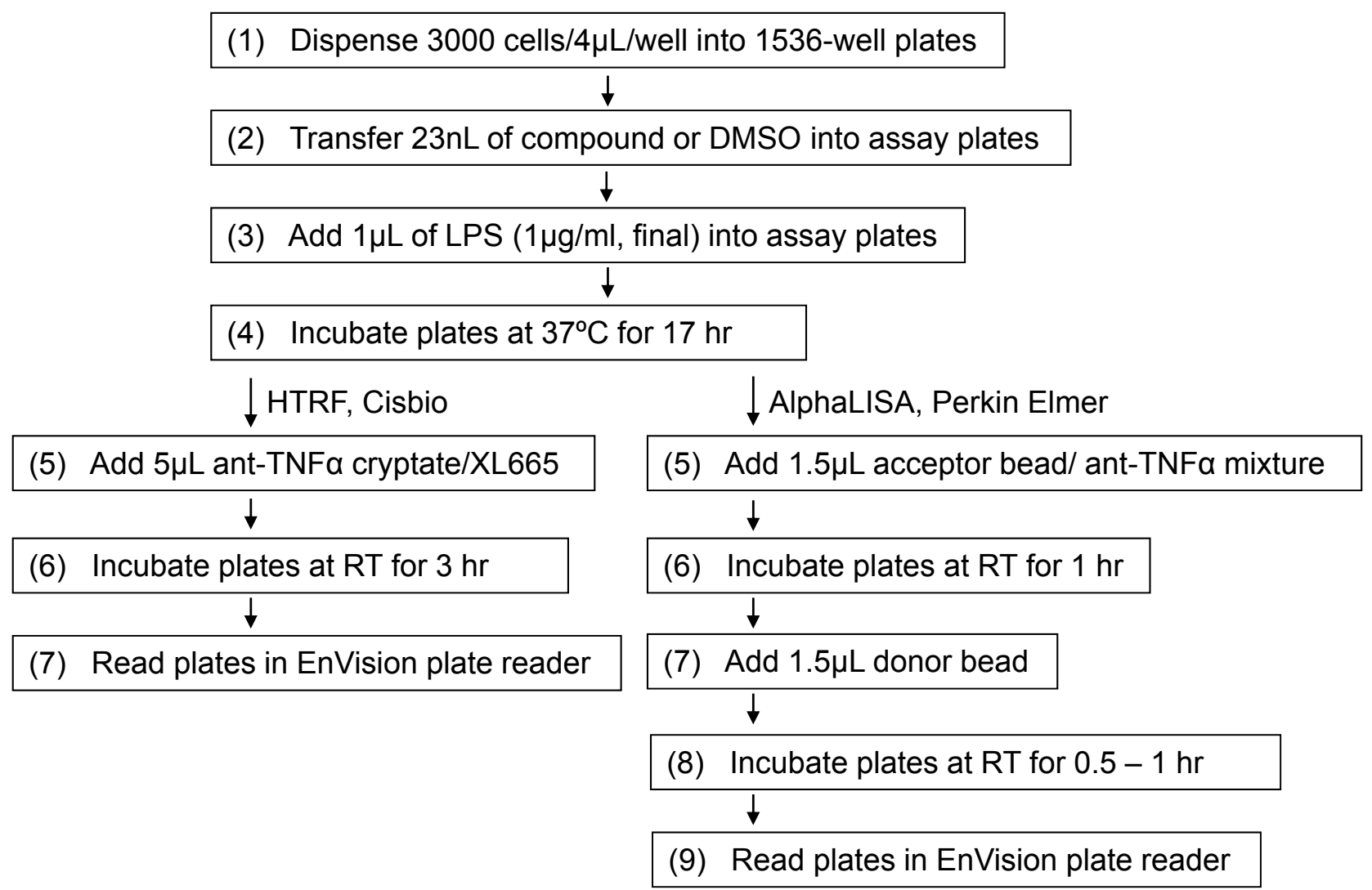

Fig. (2). qHTS protocols for HTRF-based and AlphaLISA-based TNF- $\alpha$ assays. THP-1 cells were dispensed at 3000 cells/well in $1536-w e l l$ plates. After $23 \mathrm{~nL}$ compound or DMSO only was added into the assay plates, $1 \mu \mathrm{L}$ assay medium with or without $5 \mu \mathrm{g} / \mathrm{mL} \mathrm{LPS}$ (final concentration, $1 \mu \mathrm{g} / \mathrm{mL}$ ) was added into the assay plates. The assay plates were incubated for 17 hours at $37^{\circ} \mathrm{C}$. For HTRF-based assay format, 5 $\mu \mathrm{L}$ anti-TNF $\alpha$ cryptate/XL665 mixtures were added into the assay plates. After the assay plates were incubated at RT for $3 \mathrm{hr}$, fluorescence intensity (320 nm excitation, 615 and $665 \mathrm{~nm}$ emission) was measured using an Envision plate reader (Perkin Elmer). For AlphaLISA-based assay format, $1.5 \mu \mathrm{L}$ of the mixture containing acceptor beads and anti-TNF- $\alpha$ antibody was added into each well. The assay plates were incubated in the dark at RT for $1 \mathrm{hr}$, followed by the addition of $1.5 \mu \mathrm{L}$ of donor bead. After the assay plates were incubated in the dark at RT for another 0.5 to $1 \mathrm{hr}$, the assay plates were read in the AlphaScreen mode on the Envision plate reader (Perkin Elmer).

assay using the same protocol as described above except that the 24 point titrations were laid out within one 1536-well plate.

Furthermore, the powder samples of eight compounds confirmed from the above assay were re-ordered from commercial sources and tested in the same assay protocol as described above.

\section{AlphaLISA-Based TNF- $\alpha$ Assay}

An alternative homogenous TNF- $\alpha$ assay based on PerkinElmer AlphaLISA [14, 15] assay format (Fig. 3) was used to confirm the active compounds identified from the primary screen of HTRF based assay. The cell seeding, compound addition and LPS treatment were the same as described above except the detection of TNF- $\alpha$ was using an AlphaLISA-based assay. Briefly, $1.5 \mu \mathrm{L}$ of the mixture containing acceptor beads conjugated with anti-TNF- $\alpha$ antibody was added into each well after the assay plates were incubated at $37^{\circ} \mathrm{C}$ for $17 \mathrm{hr}$. The assay plates were incubated in the dark at RT for $1 \mathrm{hr}$, followed by the addition of $1.5 \mu \mathrm{L}$ of donor bead coated with streptavidin which captures the biotinylated anti-TNF- $\alpha$ antibody. After the assay plates were incubated in the dark at RT for another $1 \mathrm{hr}$, the assay plates were read in the AlphaScreen mode on the Envision plate reader (Perkin Elmer).

\section{Cell Viability Assay}

Cell viability was measured using a luciferase-coupled ATP quantitation assay (CellTiter-Glo ${ }^{\circledR}$, Promega, Madison, WI). THP-1 were dispensed at 3000 cells/well in 1536-well white/solid bottom assay plates using a FRD, followed by addition of compounds via a pintool work station. The assay plates were incubated for $17 \mathrm{hr}$ at $37^{\circ} \mathrm{C}$. At the end of the incubation period, $5 \mu \mathrm{L}$ of CellTiter-Glo ${ }^{\circledR}$ reagent was added, plates were incubated at RT for 30 minutes, and luminescence intensity determined in the luminescence mode using a ViewLux plate reader (PerkinElmer).

\section{Measurement of TNF- $\alpha$ Using ELISA Method}

THP-1 cells were plated at the cell density of $4.8 \times 10^{4}$ in $200 \mu \mathrm{l}$ culture medium per well in a 96-well plate. Twentyfive $\mu \mathrm{L}$ culture medium with or without compound was added into each well, followed by addition of LPS at $1 \mu \mathrm{g} / \mathrm{ml}$ final concentration in culture. The final concentrations of the compounds in the wells ranged from $1.6 \mathrm{nM}$ to $30 \mu \mathrm{M}$. After $17 \mathrm{hr}$ treatment at $37^{\circ} \mathrm{C}$, the cell culture supernatants were removed and measured for human TNF- $\alpha$ using human TNF- 


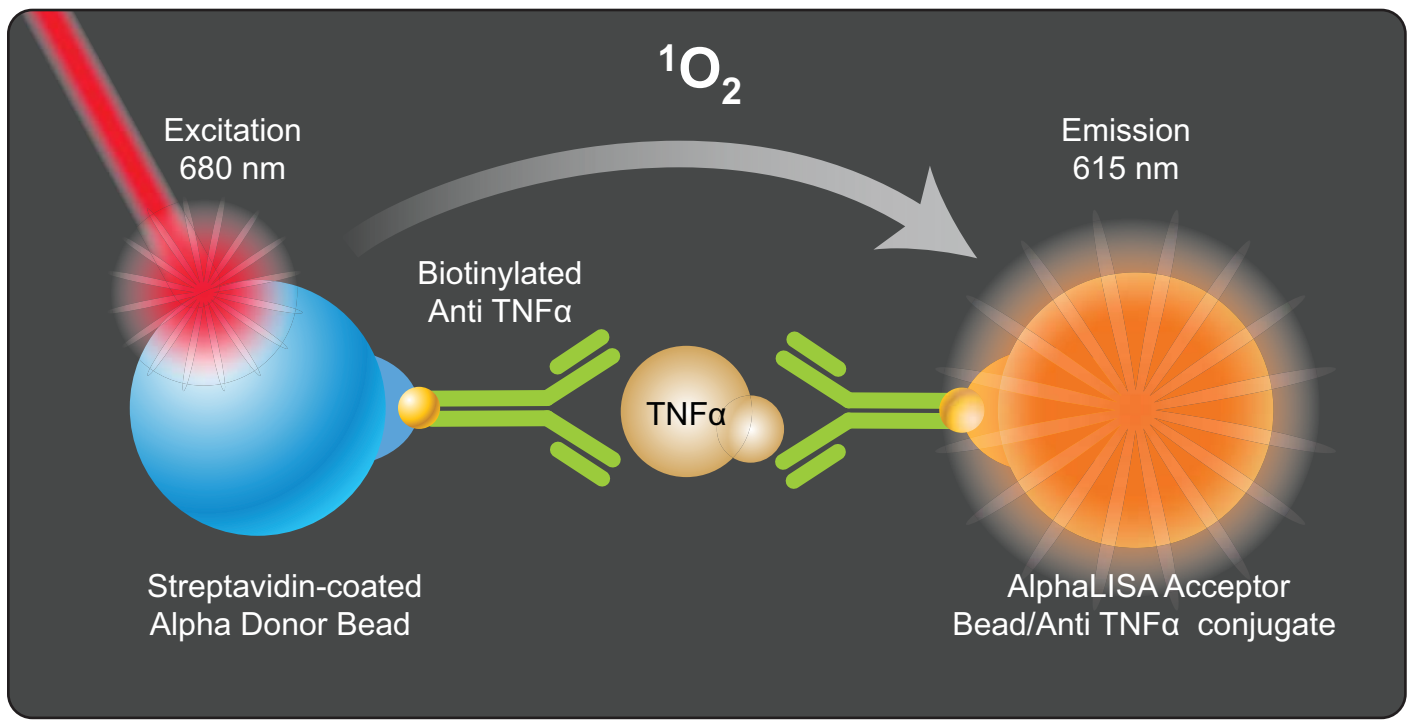

Fig. (3). Principle of AlphaLISA-based TNF- $\alpha$ assay. The Alpha donor bead (blue color) is coated with streptavidin which captures the biotinylated anti-TNF- $\alpha$ antibody. The acceptor bead (orange color) is coated with TNF- $\alpha$ specific antibody. When TNF- $\alpha$ is present, the two coated beads are brought into proximity through binding to TNF- $\alpha$. After excitation by laser at $680 \mathrm{~nm}$, the singlet oxygen released by alpha donor bead travels to the nearby acceptor bead where it causes acceptor bead to emit fluorescence at $615 \mathrm{~nm}$. The increase of AlphaLISA signal is proportional to the concentrations of TNF- $\alpha$.

$\alpha$ immunoassay kit (R\&D Systems, Minneapolis, MN). Briefly, $200 \mathrm{uL}$ of sample or known standard $(0-1000 \mathrm{pg} / \mathrm{ml})$ was added to wells of a microplate which was pre-coated with a monoclonal antibody specific for TNF- $\alpha$ and incubated at RT for $2 \mathrm{hr}$. After washing away any unbound substances, an enzyme-linked polyclonal anti-TNF- $\alpha$ antibody was added and the plate incubated for $1 \mathrm{hr}$ at RT. Following four washes, a substrate solution was added and incubated for 15-20 min, followed by the addition of a stop solution. The optical density of each well was determined at $450 \mathrm{~nm}$ with $570 \mathrm{~nm}$ as a reference filter using an EnVision plate reader.

The raw data was normalized to LPS $(1 \mu \mathrm{g} / \mathrm{mL}, 100 \%)$ and assay medium with $0.1 \%$ DMSO (basal, $0 \%$ ). The inhibition curves for each compound were analyzed using the non-linear regression analysis program in GraphPad Prism (Soft-ware).

\section{qHTS Data Analysis}

Data normalization, correction and fitting of concentration response curves were performed as previously described [16]. Briefly, raw results for each titration point was first normalized relative to the LPS control $(1 \mu \mathrm{g} / \mathrm{ml}, 0 \%)$ and DMSO only wells (basal, -100\%), and then corrected by applying a pattern correction algorithm using compound-free control plates (DMSO plates) to minimize the dispense and reading errors. Concentration-response titration points for each compound were fitted to the Hill equation yielding concentrations of half-maximal inhibition $\left(\mathrm{IC}_{50}\right)$ and maximal response (efficacy) values. Concentration response curves were classified into four major classes using the set of criteria listed in previous studies [17].

Compounds which showed inhibition in both the ratiometric and $665 \mathrm{~nm}$ readings, and had potency less than 5 $\mu \mathrm{M}$ and efficacy greater than $50 \%$ in the ratiometric reading were considered as active in the HTRF human TNF- $\alpha$ assay.
These compounds were further prioritized based on their activity in the cell viability assay after $17 \mathrm{~h}$ compound treatment. Twenty-six active compounds that were not apparently cytotoxic (6 times more potent in the HTRF human TNF- $\alpha$ assay than that in the cell viability assay) were cherry-picked for confirmation and follow up studies.

\section{RESULTS}

\section{Assay Optimization and Miniaturization of HTRF-Based TNF- $\alpha$ Assay}

We have optimized and validated a homogenous HTRFbased TNF- $\alpha$ assay in a 1536-well plate format that can be used to screen compounds to identify potential TNF- $\alpha$ inhibitors (Fig. 1). LPS, a known TNF- $\alpha$ stimulator, induced TNF- $\alpha$ production in a concentration-dependent manner after $17 \mathrm{hr}$ incubation with the THP-1 cells (Fig. 4A). The $\mathrm{EC}_{50}$ of LPS was $0.84 \mu \mathrm{g} / \mathrm{ml}$, and the maximum induction of TNF- $\alpha$ production by LPS was more than 8-fold of the basal level.

To determine the optimal incubation time, the cells were incubated with concentration titrations of LPS for 5 to $24 \mathrm{hr}$. The $\mathrm{EC}_{50} \mathrm{~s}$ of LPS are 2.52, 0.84 and $2.22 \mu \mathrm{g} / \mathrm{ml}$ for 5,17 and $24 \mathrm{hr}$ incubation, respectively. The signal-to-basal ratio under maximum LPS treatment was highest after $17 \mathrm{hr}$ of incubation (8.7-fold), followed by $24 \mathrm{hr}$ incubation (4.9-fold) and $5 \mathrm{hr}$ incubation (4.6-fold). Therefore, the $17 \mathrm{hr}$ incubation of LPS with THP-1 cells was chosen for compound treatment for the rest of the study (Fig. 4A).

The optimal cell density in a 1536-well plate format was determined by varying cell numbers in a homogenous HTRF TNF- $\alpha$ assay. The $\mathrm{EC}_{50}$ s of LPS were $0.70,0.74$ and 0.84 $\mu \mathrm{g} / \mathrm{ml}$ for 2000,3000 , and 4000 cells per well, respectively. The signal-to-basal ratios under maximum LPS treatment after $17 \mathrm{hr}$ incubation were 6.9-, 9.1-, and 9.1-fold for the cell density at 2000, 3000, and 4000 cells per well, respectively (Fig. 4B). 3000 and 4000 cells/well yielded slightly higher signal-to-basal ratios than 2000 cells/well. Thus, 3000 


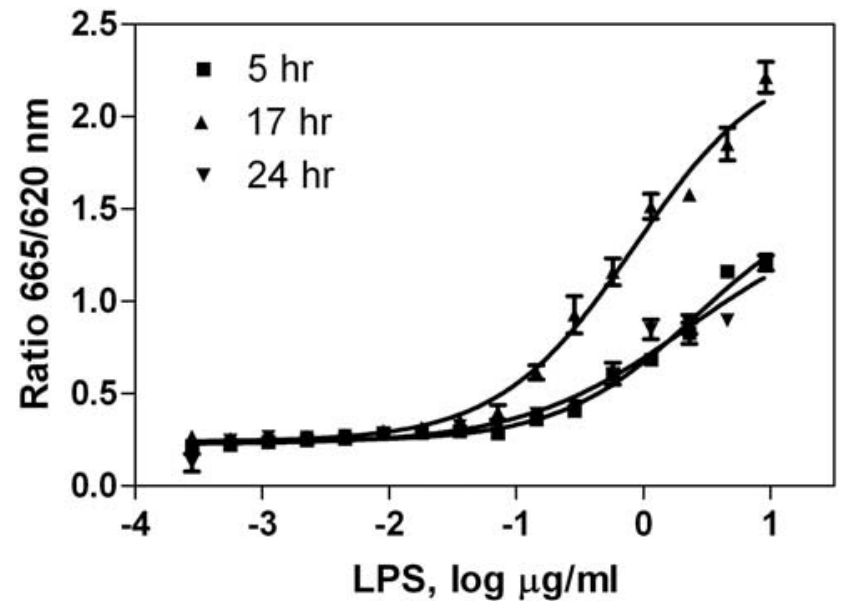

A

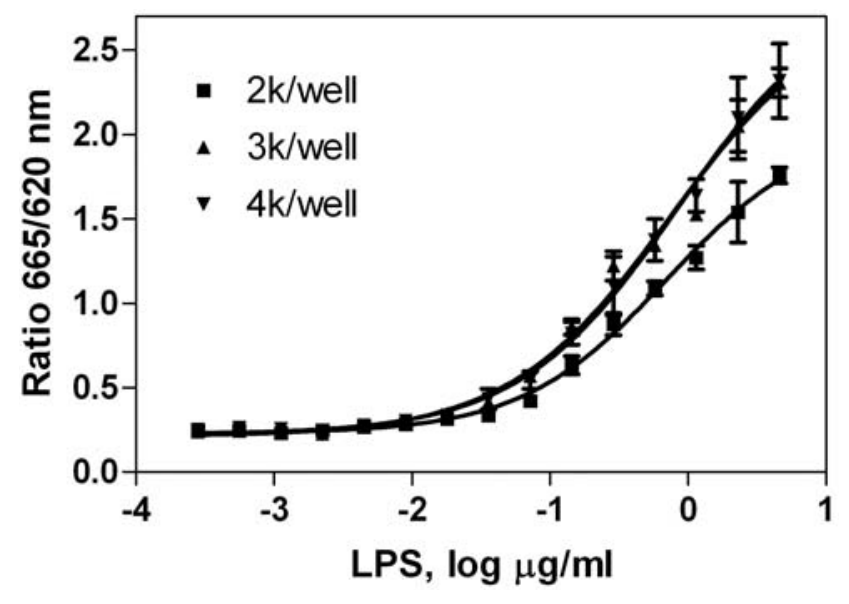

B

Fig. (4). (A) Time course of LPS-induced TNF- $\alpha$ production. THP-1 cells were treated with various LPS concentrations for 5 , 17 and 24 hr. At the end of various time points, TNF- $\alpha$ production was measured in THP-1 cells using a homogenous HTRF-based TNF- $\alpha$ assay. Data are from a single experiment performed in quadruplicate, representative of several experiments. (B) Optimization of cell density. THP-1 cells were dispensed at $2 \mathrm{k}, 3 \mathrm{k}$ and $4 \mathrm{k}$ per well. After incubated with LPS for $17 \mathrm{hr}$, TNF- $\alpha$ production in the cells was measured. Data are from a single experiment performed in quadruplicate.

cells/well was chosen to prevent possible overcrowding of cells at the higher density of 4000 cells/well.

Thus, this assay is simple and robust and is suitable for high throughput screening of compound libraries. It has been miniaturized into the 1536-well plate format to increase screen throughput and to reduce reagents consumption.

\section{LOPAC Library Screen Using qHTS}

The LOPAC library containing 1280 compounds with known pharmacological activities was screened to evaluate the HTRF TNF- $\alpha$ assay. The inhibitory effect of the compounds on TNF- $\alpha$ production was measured in the presence of $1 \mu \mathrm{g} / \mathrm{ml}\left(\mathrm{EC}_{80}\right.$ value) of LPS in a quantitative high throughput screening (qHTS) platform. The average signalto-basal ratio for LPS was $8.4 \pm 1.3$ (mean \pm SD) and the average $Z$ ' factor was $0.8 \pm 0.06$ for this primary screen, indicating a robust assay for compound library screen.

The compound potencies and efficacies were calculated from the primary results obtained from this LOPAC library screen using the HTRF-based TNF- $\alpha$ assay as it was described in the Methods section. The primary hits were selected as these compounds had $\mathrm{IC}_{50}$ values less than $1 \mu \mathrm{M}$ and inhibitory efficacy greater than $50 \%$ of control response in the HTRF TNF- $\alpha$ assay while they were inactive or 6 fold less potent in the cell viability assay. A total of 26 compounds met these criteria as potential inhibitors of TNF- $\alpha$ production and they were cherry-picked for the further follow-up studies.

\section{Confirmation of TNF- $\alpha$ Inhibitors Using an AlphaLISA- Based TNF- $\alpha$ Assay}

The 26 cherry-picked compounds were re-tested in the HTRF-based TNF- $\alpha$ assay. The inhibitory activity of LPSinduced TNF- $\alpha$ production was confirmed in 25 of 26 selected compounds (Table 1) and the confirmation rate of was $96 \%$. To eliminate the potential false positives due to the detection method used in the above assay, these 25 compounds were further evaluated in another homogeneous
TNF- $\alpha$ assay that applied the AlphaLISA assay method (Fig. 3). The assay signal in the AlphaLISA assay was measured in the AlphaScreen mode instead of the HTRF detection mode in the HTRF TNF- $\alpha$ assay. The activities of all 25 compounds were confirmed in the AlphaLISA-based TNF- $\alpha$ assay with a concordance rate of $100 \%$. The potency ranking of the compounds in these two assays was very similar. The $\mathrm{IC}_{50}$ values of these compounds in the two assay formats correlated well with an $R^{2}$ of 0.93 . Formoterol was the most potent compound among these confirmed compounds. Its $\mathrm{IC}_{50}$ values were $4 \mathrm{nM}$ and $6 \mathrm{nM}$ in both the HTRF-based assay and the AlphaLISA-based TNF- $\alpha$ assay, respectively (Table 1). Among these 25 compounds, 15 were known beta adrenergic receptor agonists including formoterol, fenoterol, alpha-methynorepinephrine, epinephrine, norepinephrine and isoproterenol. The $\mathrm{IC}_{50}$ values of these beta adrenergic receptor agonists ranged from $4 \mathrm{nM}$ (formoterol) to $3.5 \mu \mathrm{M}$ (ritodrine). PD169316 (0.12 $\mu \mathrm{M})$, a p38 MAPK kinase inhibitor, and NFKB pathway inhibitors, Bay 11-7082 (1.2 $\mu \mathrm{M})$ and Bay 11-7085 $(0.88 \mu \mathrm{M})$, were also found active in the inhibition of LPS induced TNF- $\alpha$ production. The $\mathrm{IC}_{50}$ values of these 25 compounds from both the HTRF-based TNF$\alpha$ assay and the AlphaLISA-based TNF- $\alpha$ assay are listed in Table 1. These data suggest that the two assays, the HTRF TNF- $\alpha$ assay and AlphaLISA TNF- $\alpha$ assay, are equally sensitive to inhibitors. These homogenous assays can be easily scaled up to screen a large compound library quickly and efficiently. They can also be used to counter-screen each other to eliminate the detection-related false positive compounds.

\section{Comparison of the Homogenous HTRF-Based Assay with the Traditional ELISA-Based Assay}

To further validate the TNF- $\alpha$ inhibitors identified from both the homogenous HTRF-based and the AlphaLISAbased TNF- $\alpha$ assays, eight compounds were selected based on potency and diversity of mechanism of action and purchased from commercial chemical vendors. The inhibitory effect of these compounds on LPS induced TNF- $\alpha$ 
Table 1. Potency $\left(\mu \mathrm{M}, \mathrm{IC}_{50}\right)$ and Efficacy (\% in Parenthesis) of 25 Cherry-Picked Compounds in HTRF-Based TNF- $\alpha$ Assay, AlphaLISA-Based TNF- $\alpha$ Assay, and Cell Viability Assay

\begin{tabular}{|c|c|c|c|}
\hline Compound Name & HTRF & AlphaLISA & Cytotoxicity \\
\hline (-)- $\alpha$-Methylnorepinephrine & $0.17 \pm 0.02(96)$ & $0.12 \pm 0.04(118)$ & Inactive \\
\hline Bay 11-7082 & $1.22 \pm 0.11(103)$ & $1.22 \pm 0.33(121)$ & $7.30 \pm 0.59(107)$ \\
\hline Bay 11-7085 & $0.87 \pm 0.16(100)$ & $0.74 \pm 0.17(107)$ & $10.4 \pm 2.53(103)$ \\
\hline CCG-2046 & $2.59 \pm 0.17(93)$ & $1.15 \pm 0.38(168)$ & $12.9 \pm 1.1(80)$ \\
\hline Dobutamine hydrochloride & $0.44 \pm 0.04(92)$ & $0.51 \pm 0.06(104)$ & Inactive \\
\hline Ellipticine & $4.06 \pm 1.28(108)$ & $1.57 \pm 0.41(121)$ & $14.5 \pm 1.18(110)$ \\
\hline (-)-Epinephrine bitartrate & $0.05 \pm 0.01(96)$ & $0.07 \pm 0(71)$ & Inactive \\
\hline Histamine dihydrochloride & $1.11 \pm 0.401(77)$ & $1.89 \pm 0.26(61)$ & Inactive \\
\hline IRAK-1/4 Inhibitor I & $2.68 \pm 0.37(88)$ & $1.12 \pm 0.06(103)$ & Inactive \\
\hline$( \pm)$-Isoproterenol hydrochloride & $0.016 \pm 0.001(93)$ & $0.016 \pm 0.003(100)$ & Inactive \\
\hline Isotharine mesylate & $1.83 \pm 1.69(103)$ & $2.07 \pm 0.93(98)$ & Inactive \\
\hline L(-)-Norepinephrine bitartrate & $0.12 \pm 0.01(88)$ & $0.10 \pm 0.03(170)$ & Inactive \\
\hline Metaproterenol hemisulfate & $0.52 \pm 0.10(91)$ & $0.60 \pm 0.10(104)$ & Inactive \\
\hline N-p-Tosyl-L-phenylalanine chloromethyl ketone & $2.64 \pm 0.63(94)$ & $1.08 \pm 0.26(210)$ & $29.1 \pm 2.36(125)$ \\
\hline Parthenolide & $2.51 \pm 0.28(103)$ & $1.30 \pm 0.50(120)$ & $8.89 \pm 2.84(79)$ \\
\hline
\end{tabular}

Each value is the mean $\pm \mathrm{SD}$ of the results from two experiments in duplicates.

production in THP-1 cells was determined using a traditional ELISA assay that is the gold standard for cytokine measurement. As shown in Table 2, all eight compounds inhibited LPS induced TNF- $\alpha$ production with $\mathrm{IC}_{50} \mathrm{~s}$ ranging from 10 $\mathrm{nM}$ to $1.95 \mu \mathrm{M}$. It was notable that the potencies of all the compounds tested in the ELISA-based assay were higher than the potencies obtained from the HTRF-based assay, with $\mathrm{IC}_{50}$ shifts ranging from 2- to 7-fold (Table 2). For example, Bay 11-7085 had higher potency in the ELISA-based assay $\left(\mathrm{IC}_{50}, 0.293 \mu \mathrm{M}\right)$ than in the HTRF-based assay ( $\mathrm{IC}_{50}$, $1.43 \mu \mathrm{M}$ ), with a 4.9 -fold $\mathrm{IC}_{50}$ shift (Fig. 5A). The $\mathrm{IC}_{50}$ shifts of CCG-2046 $(2.32 \mu \mathrm{M}$ in the HTRF assay, and $0.66 \mu \mathrm{M}$ in the ELISA assay, Fig. 5B), IRAK-1/4 inhibitor I (2.76 $\mu \mathrm{M}$ in HTRF assay, and $0.52 \mu \mathrm{M}$ in ELISA assay, Fig. 5C), and PD 169316 (78.2 $\mathrm{nM}$ in HTRF assay, and $10.6 \mathrm{nM}$ in ELISA assay, Fig. 5D) were 4-, 5- and 7-fold, respectively. The other four compounds, BTO-1, dobutamine, ellipticine and histamine, had 2 to 3 -fold $\mathrm{IC}_{50}$ shifts (Table 2). However, the ranking orders of the compound potencies were comparable between the two assay formats. The $\mathrm{IC}_{50}$ values of these compounds in both the ELISA-based and HTRF-based assays correlated very well with an $R^{2}$ of 0.93 . In addition, these eight compounds were also tested in a cell viability assay to evaluate the potential cytotoxicity because the cytotoxic compounds could show the false effect on the reduction of TNF- $\alpha$ production in the cell based assays. We found that all these compounds showed none or weak cytotoxic effect (Table 2). Taken together, these data suggest that the homogenous HTRF-based TNF- $\alpha$ assays can be used to identify small molecule compounds that inhibit TNF- $\alpha$ production.

\section{DISCUSSION}

The measurements of cytokine levels in serum and tissues are important to study the immune response, inflammatory disease status and drug responses. Radioimmunoassay (RIA) was first developed to measure the concentration of insulin in plasma [18]. RIA is a sensitive in vitro method that is also applied to measure other antigen and cytokines. 
Table 2. Comparison of Potency $\left(\mu \mathrm{M}, \mathrm{IC}_{50}\right.$ ) of Commercial Ordered Compounds in ELISA-Based TNF- $\alpha$, HTRF-Based TNF- $\alpha$, and Cell Viability Assays

\begin{tabular}{|c|c|c|c|}
\hline Compound Name & ELISA & HTRF & $1.45 \pm 0.11$ \\
\hline \hline Bay 11-7085 & $0.33 \pm 0.15$ & $4.61 \pm 0.37$ & 12.9 \\
\hline BTO-1 & $1.95 \pm 0.7$ & $2.44 \pm 0.002$ & 8.66 \\
\hline CCG-2046 & $0.64 \pm 0.09$ & $0.21 \pm 0.02$ & $1.38 \pm 0.22$ \\
\hline Dobutamine hydrochloride & $0.09 \pm 0.05$ & $1.37 \pm 0.003$ & Inactive \\
\hline Ellipticine & $0.44 \pm 0.07$ & $3.14 \pm 1.69$ & Inactive \\
\hline Histamine dihydrochloride & $0.71 \pm 0.31$ & $0.07 \pm 0.01$ & 25.9 \\
\hline IRAK-1/4 Inhibitor I & $0.54 \pm 0.1$ & $0.01 \pm 0.001$ & \\
\hline PD 169316 &
\end{tabular}

Each value in ELISA and HTRF-based assays is the mean \pm SD of the results from two experiments in duplicates. Cell viability assay was performed in duplicates from one experiment.
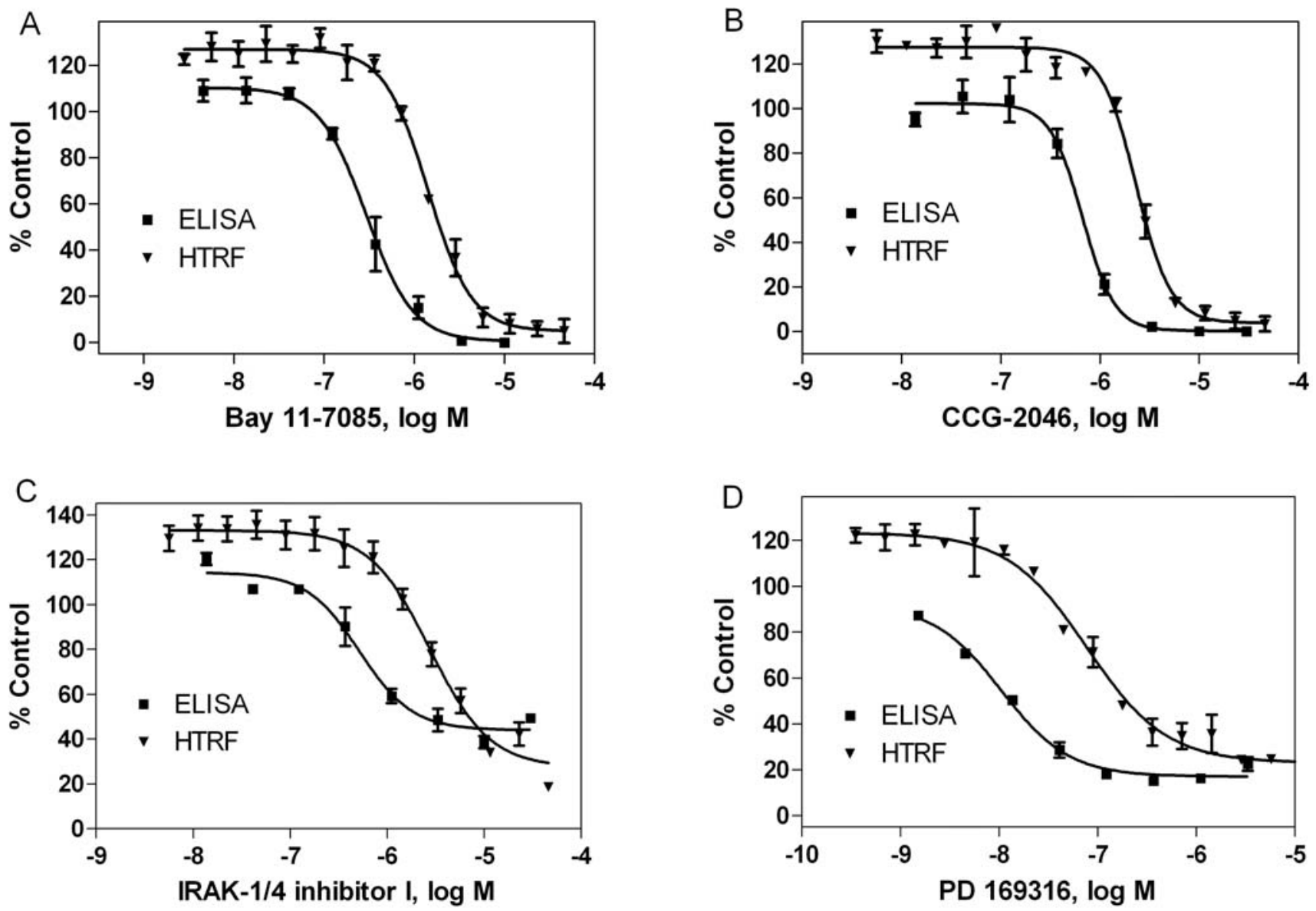

Fig. (5). Concentration response curves of TNF- $\alpha$ inhibitors in a HTRF-based TNF- $\alpha$ assay ( $\mathbf{\nabla})$ and ELISA-based assay ( $\mathbf{\square})$. TNF- $\alpha$ level was measured after THP-1 cells were incubated with various concentrations of Bay 11-7085 (A), CCG-2046 (B), IRAK-1/4 inhibitor (C) and PD 169316 (D) in the presence of $1 \mu \mathrm{g} / \mathrm{ml}$ LPS for $17 \mathrm{hr}$.

Although this assay is sensitive and specific, it requires the use of radioisotope and thus produces the radioactive waste. The RIA assay involves a specific antibody that recognizes the radioactive labeled cytokine tracer and multiple assay steps including extensive wash cycles. In the 1970s, ELISA $[19,20]$, also known as an enzyme immunoassay (EIA), was introduced, where the specific antigen (cytokine)-antibody reaction was measured using colorimetric readout instead of a radioactive signal. In the ELISA method, two specific antibodies are usually used with one antibody linked to a reporter enzyme. After several extensive reagent additions and plate washes, the substrate is added and a color change re- 
sults from an enzyme reaction due to the binding of cytokine to enzyme linked antibody. The intensity of the color produced is proportional to the levels of the cytokine such as TNF- $\alpha$. The ELISA method is widely utilized in biomedical research because it doesn't use radioactivity and is a standard method used in immunological experiments to detect cytokines.

For the large scale compound library screening, the throughput using ELISA is low and the assay procedure is complicated because the ELISA assay requires extensive wash cycles and antibody pre-coated plates. Therefore, the homogenous and simple assay method for measurement of cytokine level is needed for compound library screens. The assay should be miniaturized into high plate density formats such as 384-well and 1536-well plates as well as being sensitive to compounds. We have optimized the HTRF-based and AlphaLISA-based TNF- $\alpha$ assay into the homogenous format. The detection reagents are directly added into the wells of the assay plate treated with stimulant and compounds without involving the medium transferring that is needed in the original assay protocol. We found that the activities of TNF$\alpha$ inhibitors identified in these homogenous assays were well correlated with those obtained from the ELISA-based assay.

Compared to the traditional ELISA method, these assays can be easily miniaturized into a 1536-well plate format and are homogeneous, and no plate wash or supernatant transfer steps. The frequent plate incubations needed in the ELISA assay was reduced significantly. Furthermore, the ratiometric readout from the dual emissions (665 and $615 \mathrm{~nm}$ ) used in the HTRF-based TNF- $\alpha$ assay minimizes the well-to-well and plate-to-plate variations that are caused by subtle differences in cell numbers and dispensing error.

We also found that the potencies of compounds obtained in the HTRF-based TNF- $\alpha$ assay were slightly lower than those measured in the ELISA method. Among these compounds tested, a 2- to 7-fold shift of activities was observed. This could be due to the fact that ELISA can have increased sensitivity because it is a plate based, and fixed assay system which increases the capture ability of the antibody. Also, the many wash steps in the ELISA protocol will remove any non-specific binding of the antibody. Finally, the antibodies used in the different assays may have different affinities for the antigen, resulting in different sensitivity of the assay. However, the potency ranking orders of compounds tested in ELISA and homogenous assay formats were similar. Therefore, both the HTRF-based and AlphaLISA-based TNF- $\alpha$ assays are still preferable for high throughput screening of large compound collection. The ELISA based TNF- $\alpha$ assay can be used as a confirmation assay to validate the active compounds identified from the primary screens.

Beta-adrenergic agonists are known to suppress LPSinduced TNF- $\alpha$ production [21]. After a beta-adrenergic agonist binds to its receptor, adenylyl cyclase (AC) is activated by $G_{S} \alpha$ protein which leads to an increase of intracellular cAMP. It has been shown that the increased cAMP stimulated by beta-adrenergic agonists can reduce the TNF- $\alpha$ mRNA levels [22]. Consistent with previous reports, we found more than a dozen beta adrenergic agonists including norepinephrine, epinephrine, dobutamine and fenoterol from the LOPAC library with an inhibitory effect on TNF- $\alpha$ production. In addition, we also found that histamine inhibited
LPS-induced TNF- $\alpha$ production in THP-1 cells, which is consistent with a previous report that histamine suppressed the LPS-induced synthesis of TNF- $\alpha$ in peripheral blood mononuclear cells [23]. The inhibition of histamine on TNF$\alpha$ production is caused by a similar mechanism as the beta adrenergic agonists. Histamine binds to and activates the histamine type $2(\mathrm{H} 2)$ receptor that resulting in activation of $\mathrm{G}_{\mathrm{S}} \alpha$ protein, and $\mathrm{AC}$ and thus increasing intracellular cAMP [23].

The binding of TNF- $\alpha$ to its receptor initiates the signaling cascade resulting in activation of the NF- $\kappa B$ and MAP kinase signaling pathways [7]. Previous studies reported that Bay 11-7082 [24], Bay 11-7085 [25], N-p-tosyl-Lphenylalanine chloromethyl ketone [26], IRAK-1/4 inhibitor I [27], and parthenolide [28] had inhibitory effects on the NF- $\kappa \mathrm{B}$ signaling pathway. PD 169316 [29] was reported to inhibit the p38 MAP kinase. These compounds were found in our LOPAC library screen to inhibit the LPS induced TNF- $\alpha$ production in THP- 1 cells, suggesting that the inhibition of NF- $\mathrm{KB}$ and MAP kinase signaling pathways by these compounds could be a result of the inhibition of TNF- $\alpha$ production.

BTO-1, CCG-2046, and ellipticine were identified as inhibitors of LPS induced TNF- $\alpha$ production from this LOPAC library screen. BTO-1 is a polo-like kinase I inhibitor, which inhibits spindle assembly, mitotic entry and chromosome segregation [30]. Ellipticine, an alkaloid derived from the leaves of the evergreen tree, is known as a DNA intercalating agent [31] and an inhibitor of the enzyme topoisomerase II [32]. However, the roles of these compounds and the mechanism of action on LPS-induced TNF- $\alpha$ production still need further investigation. These compounds might be useful as research tools in the fields of inflammation and immunology.

In summary, we have optimized and validated two homogenous TNF- $\alpha$ assays using HTRF and AlphaLISA assay formats. Both assays were miniaturized into 1536-well plates in a qHTS format. From a test screen of the LOPAC library, we have identified twenty-five TNF- $\alpha$ inhibitors. All these compounds showed reproducible activities in these two assays. Eight out of the 25 compounds were further evaluated in the traditional ELISA based TNF- $\alpha$ assay. The $\mathrm{IC}_{50}$ values of these compounds measured from the homogenous HTRFbased TNF- $\alpha$ assay correlated very well with those determined in the TNF- $\alpha$ ELISA assay. Out of the 25 compounds, 15 are beta adrenergic receptor agonists, five are known inhibitors of the NF- $\mathrm{KB}$ pathway, and one compound is a histamine $\mathrm{H} 2$ receptor agonist. The identification of these 21 known inhibitors further demonstrated that these two homogenous TNF- $\alpha$ assays reported here are valid for compound screening. We also found four compounds including BTO-1, CCG-2046, ellipticine, and PD 169316 as new inhibitors of LPS induced TNF- $\alpha$ production. Taken together, our results indicated that these homogenous TNF- $\alpha$ assays can be used to quickly and efficiently screen large compound collections and to identify compounds that can potentially inhibit TNF- $\alpha$ production.

\section{ACKNOWLEDGEMENTS}

We thank Darryl Leja for illustrations. This work was supported by the Intramural Research Program of the Na- 
tional Human Genome Research Institute, National Institutes of Health.

\section{REFERENCES}

[1] Eigler A, Sinha B, Hartmann G, Endres S. Taming TNF: strategies to restrain this proinflammatory cytokine. Immunol Today 1997; 18: 487-92.

[2] Shakhov AN, Collart MA, Vassalli P, Nedospasov SA, Jongeneel CV. Kappa B-type enhancers are involved in lipopolysaccharidemediated transcriptional activation of the tumor necrosis factor alpha gene in primary macrophages. J Exp Med 1990; 171: 35-47.

[3] Yao J, Mackman N, Edgington TS, Fan ST. Lipopolysaccharide induction of the tumor necrosis factor-alpha promoter in human monocytic cells. Regulation by Egr-1, c-Jun, and NF-kappaB transcription factors. J Biol Chem 1997; 272: 17795-801.

[4] Martich GD, Danner RL, Ceska M, Suffredini AF. Detection of interleukin 8 and tumor necrosis factor in normal humans after intravenous endotoxin: the effect of antiinflammatory agents. J Exp Med 1991; 173: 1021-4.

[5] Carswell EA, Old LJ, Kassel RL, Green S, Fiore N, Williamson B. An endotoxin-induced serum factor that causes necrosis of tumors. Proc Natl Acad Sci U S A 1975; 72: 3666-70.

[6] Dempsey PW, Doyle SE, He JQ, Cheng G. The signaling adaptors and pathways activated by TNF superfamily. Cytokine Growth Factor Rev 2003; 14: 193-209.

[7] Paul AT, Gohil VM, Bhutani KK. Modulating TNF-alpha signaling with natural products. Drug Discov Today 2006; 11: 725-32.

[8] Kam LY, Targan SR, TNF-alpha antagonists for the treatment of Crohn's disease. Expert Opin Pharmacother 2000; 1: 615-22.

[9] Nakamura K, Honda K, Mizutani T, Akiho H, Harada N. Novel strategies for the treatment of inflammatory bowel disease: Selective inhibition of cytokines and adhesion molecules. World J Gastroenterol 2006; 12: 4628-35.

[10] Xia M, Guo V, Huang R, Inglese J, Nirenberg M, Austin CP. A Cell-based beta-Lactamase Reporter Gene Assay for the CREB Signaling Pathway. Curr Chem Genom 2009; 3: 7-12.

[11] Tsuchiya S, Yamabe M, Yamaguchi Y, Kobayashi Y, Konno T, Tada K. Establishment and characterization of a human acute monocytic leukemia cell line (THP-1). Int J Cancer 1980; 26: 1716.

[12] Degorce F, Card A, Soh S, Trinquet E, Knapik GP, Xie B. HTRF: A technology tailored for drug discovery - a review of theoretical aspects and recent applications. Curr Chem Genom 2009; 3: 22-32.

[13] Harbert C, Marshall J, Soh S, Steger K. Development of a HTRF kinase assay for determination of Syk activity. Curr Chem Genom 2008; 1: 20-6.

[14] Du Y, Khuri FR, Fu H. A homogenous luminescent proximity assay for 14-3-3 interactions with both phosphorylated and nonphosphorylated client peptides. Curr Chem Genom 2008; 2: 40-7.

[15] Eglen RM, Reisine T, Roby P, et al. The use of AlphaScreen technology in HTS: current status. Curr Chem Genom 2008; 1: 2-10.

[16] Xia M, Huang R, Witt KL, et al. Compound cytotoxicity profiling using quantitative high-throughput screening. Environ Health Perspect 2008; 116: 284-91.
[17] Inglese J, Auld DS, Jadhav A, et al. Quantitative high-throughput screening: a titration-based approach that efficiently identifies biological activities in large chemical libraries. Proc Natl Acad Sci U S A 2006; 103: 11473-8.

[18] Yalow RS, Berson SA. Assay of plasma insulin in human subjects by immunological methods. Nature 1959; 184 (Suppl 21): 1648-9.

[19] Engvall E, Perlmann P. Enzyme-linked immunosorbent assay (ELISA). Quantitative assay of immunoglobulin G. Immunochemistry $1971 ; 8: 871-4$.

[20] Van Weemen BK, Schuurs AH. Immunoassay using antigenenzyme conjugates. FEBS Lett 1971; 15: 232-6.

[21] Ye RD. beta-Adrenergic agonists regulate NF-kappaB activation through multiple mechanisms. Am J Physiol Lung Cell Mol Physiol 2000; 279: L615-7.

[22] Talmadge J, Scott R, Castelli P, Newman-Tarr T, Lee J. Molecular pharmacology of the beta-adrenergic receptor on THP-1 cells. Int J Immunopharmacol 1993; 15: 219-28.

[23] Vannier E, Miller LC, Dinarello CA. Histamine suppresses gene expression and synthesis of tumor necrosis factor alpha via histamine H2 receptors. J Exp Med 1991; 174: 281-4.

[24] Li B, Li YY, Tsao SW, Cheung AL. Targeting NF-kappaB signaling pathway suppresses tumor growth, angiogenesis, and metastasis of human esophageal cancer. Mol Cancer Ther 2009; 8: 2635-44.

[25] Hernandez-Gutierrez S, Garcia-Pelaez I, Zentella-Dehesa A, et al. NF-kappaB signaling blockade by Bay 11-7085 during early cardiac morphogenesis induces alterations of the outflow tract in chicken heart. Apoptosis 2006; 11: 1101-9.

[26] Choi J, Ha KH, Byun MS, et al. Treatment with N-tosyl-1phenylalanine chloromethyl ketone after the onset of collageninduced arthritis reduces joint erosion and NF-kappaB activation. Eur J Pharmacol 2008; 595: 108-13.

[27] Bhattacharyya S, Borthakur A, Pant N, Dudeja PK, Tobacman JK. Bc110 mediates LPS-induced activation of NF-kappaB and IL-8 in human intestinal epithelial cells. Am J Physiol Gastrointest Liver Physiol 2007; 293: G429-37.

[28] Yip KH, Zheng MH, Feng HT, Steer JH, Joyce DA, Xu J. Sesquiterpene lactone parthenolide blocks lipopolysaccharide-induced osteolysis through the suppression of NF-kappaB activity. J Bone Miner Res 2004; 19: 1905-16.

[29] Tokuda H, Kanno Y, Ishisaki A, Takenaka M, Harada A, Kozawa O. Interleukin (IL)-17 enhances tumor necrosis factor-alphastimulated IL-6 synthesis via p38 mitogen-activated protein kinase in osteoblasts. J Cell Biochem 2004; 91: 1053-61.

[30] Brennan IM, Peters U, Kapoor TM, Straight AF. Polo-like kinase controls vertebrate spindle elongation and cytokinesis. PLoS One 2007; 2: e409.

[31] Tewey KM, Chen GL, Nelson EM, Liu LF. Intercalative antitumor drugs interfere with the breakage-reunion reaction of mammalian DNA topoisomerase II. J Biol Chem 1984; 259: 9182-7.

[32] Huff AC, Kreuzer KN. Evidence for a common mechanism of action for antitumor and antibacterial agents that inhibit type II DNA topoisomerases. J Biol Chem 1990; 265: 20496-505.

(C) Leister et al.; Licensee Bentham Open.

This is an open access article licensed under the terms of the Creative Commons Attribution Non-Commercial License (http://creativecommons.org/licenses/by-nc/3.0/) which permits unrestricted, non-commercial use, distribution and reproduction in any medium, provided the work is properly cited. 